DOI: https://doi.org/10.24843/JFU.2019.v08.i01.p02

pISSN: 2301-7716; eISSN: 2622-4607

Jurnal Farmasi Udayana, Vol 8, No 1, Tahun 2019, 7-13

\title{
SGLT-2 Inhibitor: Pilihan Terapi Baru untuk Penderita DM Tipe 2
}

\author{
Sarasmita, M. A. ${ }^{1}$, Amandari, I. G. A. A. E. ${ }_{1}^{1}$, Dewi, N. P. U. S. ${ }^{1}$, Krisnayanti, M. W. \\ ${ }^{1}$ Program Studi Farmasi Fakultas Matematika dan Ilmu Pengetabuan Alam Universitas Udayana, Jalan Kampus \\ Unud, Jimbaran, 80364
}

Email:arysarasmita@yahoo.com

\begin{abstract}
ABSTRAK
Penyakit diabetes melitus tipe 2 (DMT2) merupakan suatu kondisi medis yang ditandai dengan adanya peningkatan kadar glukosa darah melebihi batas normal. World Health Organization (WHO) menyebutkan bahwa jumlah penderita DM di Indonesia mengalami peningkatan dari 8,4 juta penderita pada tahun 2000 menjadi 21,3 juta penderita pada tahun 2030, dimana $90 \%$ diantaranya merupakan penderita DMT2. Patofisiologi dari penyakit DMT2 adalah suatu proses yang kompleks dan melibatkan banyak faktor. Konsep ominous octet yang dikemukakan oleh Ralph DeFronzo memegang peranan penting untuk menjelaskan patofisiologi dari DMT2. Ginjal merupakan organ yang memiliki peran signifikan untuk mengendalikan glukosa darah agar tetap dalam batas yang normal, sehingga dipertimbangkan untuk menjadi target terapi obat baru. Sodium glucose co-transporters (SGLTs) diantaranya SGLT-2 memfasilitasi reabsorbsi glukosa kedalam plasma. Farmakokinetika dari SGLT-2 inhibitor secara umum menunjukkan bioavailabilitas yang baik saat diberikan melalui oral. Diabetes melitus merupakan faktor risiko terjadinya penyakit ginjal kronik (PGK) dan penyakit kardiovaskuler (PKV). Adanya mekanisme penghambatan pada SGLT-2 akan memberikan manfaat terhadap sistem reno-kardiovaskuler melalui penurunan glukosa darah, berat badan, dan tekanan darah. Penghambat SGLT-2 memiliki beberapa efek tambahan yang menguntungkan untuk sindrom metabolik, seperti penurunan berat badan, penurunan tekanan darah (terutama sistolik), serta penurunan asam urat serum
\end{abstract}

Kata kunci: Diabetes melitus, glukosuria, reabsorbsi, SGLT-2 inbibitor

\section{ABSTRACT}

Type 2 diabetes mellitus (DMT2) is a medical condition characterized by an increase in blood glucose levels exceeding normal limits. World Health Organization (WHO) states that the number of DMT2 patients in Indonesia has increased from 8.4 millions patients in 2000 to 21.3 milliom patients in 2030, which is 90\% of them are patients with DMT2. Pathophysiology of DMT2 is a complex process and involves many factors. The ominous octet concept proposed by Ralph DeFronzo plays an important role to explain the pathophysiology of DMT2. The kidneys are organs that have a significant role to control blood glucose to stay within normal limits, thus being considered to be targets of new drug therapies. Sodium glucose co-transporters (SGLTS) such as SGLT-2 facilitate the reabsorption of glucose into plasma. Pharmacokinetics of the SGLT-2 inhibitors generally show gool bioavailability when admistered orally. DMT2 is a risk factor for chronis kidney disease (CKD) and cardiovascular disease (CVD). The presence of an inbibitory mechanism in SGLT-2 will benefit the reno-cardiovascular system through decreased blood glucose, weight, and blood pressure. SGLT-2 inbibitors have some favorable adjunctive effects for metabolic syndrome, such as weight loss, decreased blood pressure (especially systolic), as well as decreased serum uric acid.

Keyword: Diabetes mellitus, glucosuria, reabsorption, SGLT-2 inbibitor 
DOI: https://doi.org/10.24843/JFU.2019.v08.i01.p02

pISSN: 2301-7716; eISSN: 2622-4607

Jurnal Farmasi Udayana, Vol 8, No 1, Tahun 2019, 7-13

\section{PENDAHULUAN}

Penyakit diabetes melitus tipe 2 (DMT2) merupakan suatu kondisi medis yang ditandai dengan adanya peningkatan kadar glukosa dalam darah melebihi batas normal, biasanya disebabkan oleh tubuh tidak dapat memanfaatkan insulin secara efisien. DMT2 merupakan faktor risiko dari beberapa komplikasi makrovaskuler seperti penyakit jantung koroner, serebrovaskuler, dan gangguan pembuluh darah perifer serta komplikasi mikrovaskuler seperti retinopati, nefropati, dan neuropati (Luman, 2015).

Populasi global penderita DM pada tahun 2015 mencapai 7,3 miliar jiwa, sedangkan pada tahun 2040 diperkirakan meningkat dan mencapai angka 9 miliar jiwa (Ogurtsova, dkk., 2017). World Health Organization (WHO) menyebutkan bahwa jumlah penderita DM di Indonesia mengalami peningkatan dari 8,4 juta penderita pada tahun 2000 menjadi sekitar 21,3 juta penderita pada tahun 2030, dimana 90\% diantaranya merupakan penderita DM tipe 2 (Perkeni, 2006; Syaripuddin, 2013).

Patofisiologi dari penyakit DM tipe 2 merupakan suatu proses yang kompleks dan melibatkan banyak faktor. Konsep ominous octet yang dikemukakan oleh Ralph DeFronzo memegang peranan penting untuk menjelaskan patofisiologi dari DM tipe 2 (gambar 1). Kegagalan sel beta pankreas dan resistensi insulin pada otot dan hati merupakan defek utama yang terjadi. Selanjutnya terjadi defisiensi incretin, lipolisis meningkat, hiperglukagonemia, resistensi insulin di otak, dan peningkatan absorbsi glukosa di renal yang juga dapat menjadi akibat dari perkembangan penyakit (Santos., dkk., 2017).

Ginjal merupakan organ yang memiliki peran signifikan untuk mengendalikan glukosa darah agar tetap dalam batas yang normal, sehingga dipertimbangkan untuk menjadi target terapi obat baru. Sodium glucose cotransporters (SGLTs) yang terdiri dari SGLT-1 dan SGLT-2 memfasilitasi reabsorbsi glukosa kembali kedalam plasma. Penghambatan proses ini akan menyebabkan glukosuria dan juga dapat menurunkan kadar glukosa darah. (Edward dan Chao, 2014).

Review ini akan membahas secara umum karakteristik penghambat SGLT-2 sebagai antidiabetes jenis baru dan penggunaannya secara klinis. 
DOI: https://doi.org/10.24843/JFU.2019.v08.i01.p02

pISSN: 2301-7716; eISSN: 2622-4607

Jurnal Farmasi Udayana, Vol 8, No 1, Tahun 2019, 7-13

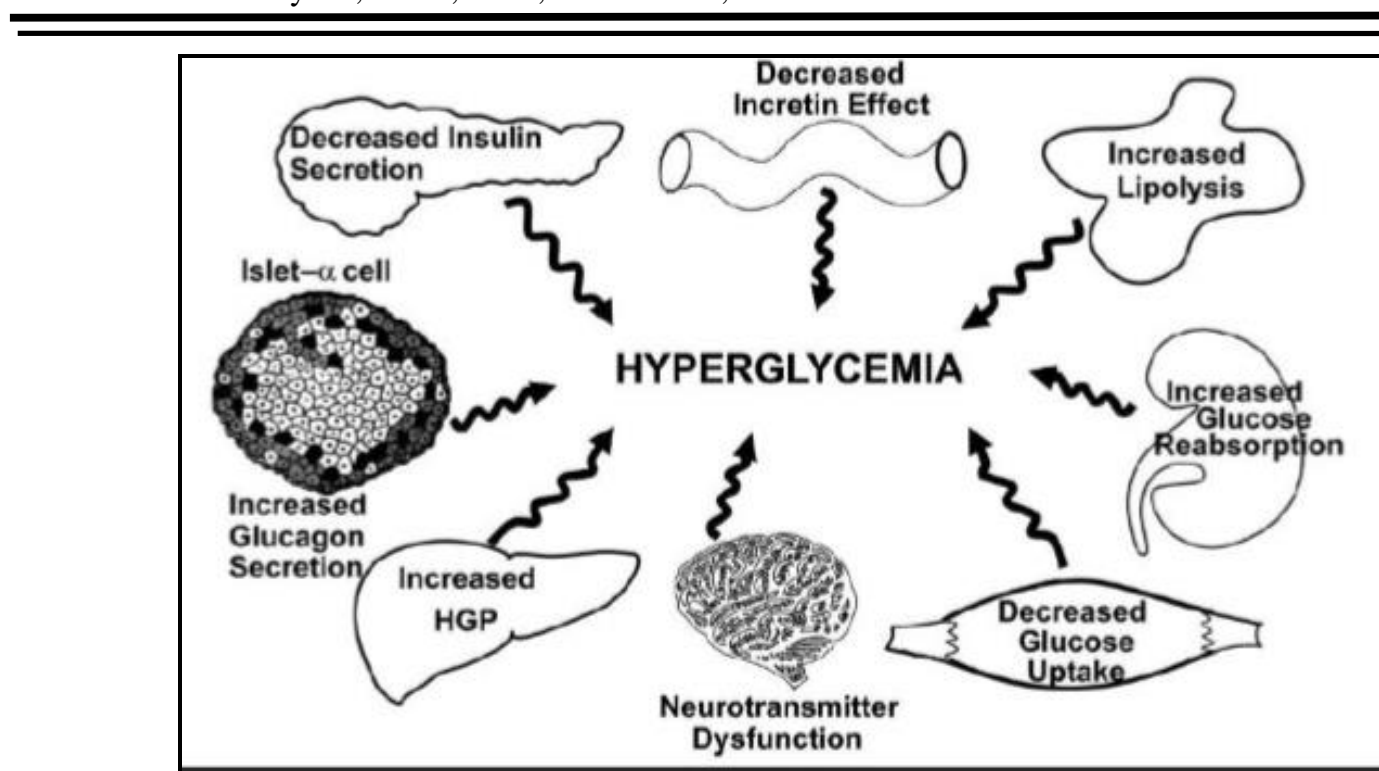

Gambar 1. Patofisiologi penyakit diabetes melitus tipe 2 (ominous octet) (Santos, dkk., 2017).

\section{SGLT-2 INHIBITOR}

Terapi obat untuk menurunkan kadar glukosa darah yang konvensional, seperti sulfonilurea, metformin, dan insulin umunya dibatasi oleh adanya efek samping pada gastrointestinal, hipoglikemia, dan peningkatan berat badan. Terapi thiazolidinedione berhubungan dengan peningkatan berat badan, masalah kardiovaskuler, peningkatan risiko fraktur, dan retensi cairan. Penggunaan analog glucagon-like-peptide-1 (GLP-1) sering dibatasi karena dapat memberikan penurunan berat badan yang moderat. Selain itu analog GLP-1 memiliki efek samping pada gastrointestinal. Peningkatan prevalensi diabetes melitus tipe 2 yang dikombinasi dengan keterbatasaan terapi konvensional akan membutuhkan terapi baru yang dapat menjadi alternatif untuk mengurangi morbiditas dan mortalitas akibat diabetes melitus tipe 2 (Luman, 2015).

Sodium-glucose cotransporter 2 (SGLT-2) inbibitor merupakan terapi antidiabetes jenis baru yang digunakan untuk mengatasi diabetes melitus tipe 2. Sebagaimana diketahui melalui gambar 2 bahwa ginjal memiliki kontribusi penting untuk menyeimbangkan kadar glukosa darah agar tetap dalam batas normal. SGLT-2 memungkinkan glukosa darah yang masuk ke dalam ginjal akan direabsorbsi kembali menuju plasma, sehingga SGLT-2 merupakan target yang potensial untuk terapi baru untuk DM tipe 2 (Chen dan Leung, 2013). 
DOI: https://doi.org/10.24843/JFU.2019.v08.i01.p02

pISSN: 2301-7716; eISSN: 2622-4607

Jurnal Farmasi Udayana, Vol 8, No 1, Tahun 2019, 7-13

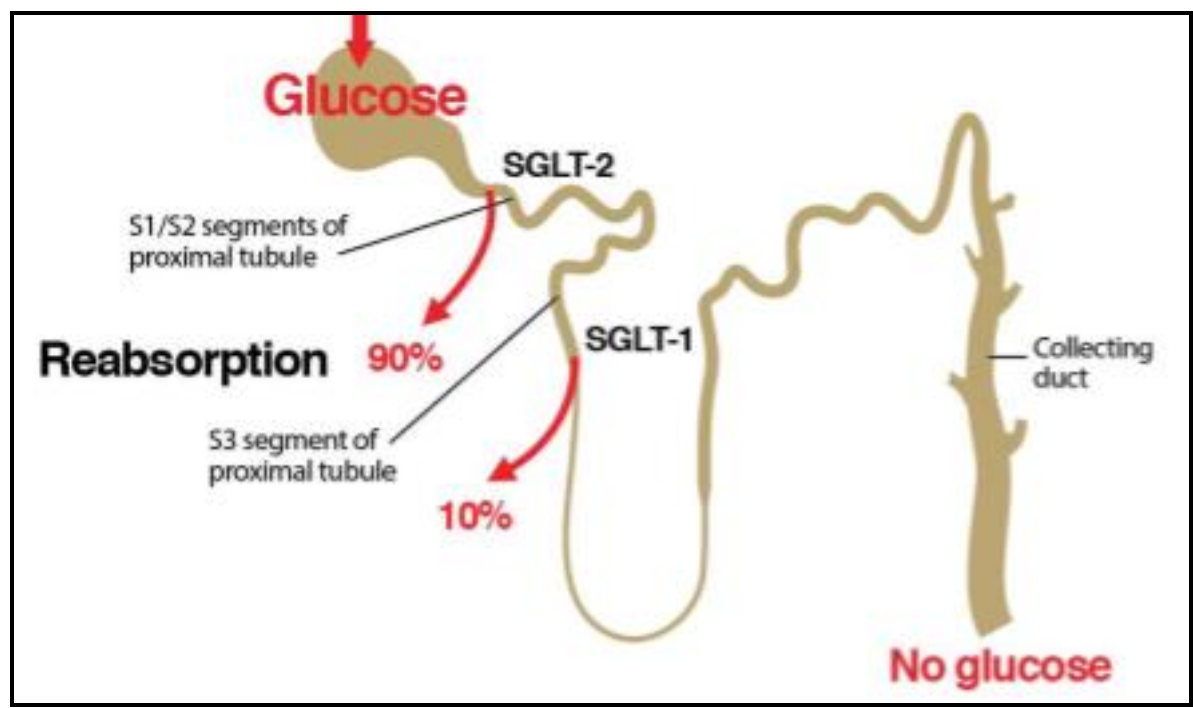

Gambar 2. Proses reabsorbsi glukosa yang terjadi dalam ginjal (Chao, 2014).

\section{MEKANISME KERJA SGLT-2 INHIBITOR}

SGLT-2 inbibitors bekerja dengan cara menghambat reabsorbsi glukosa di tubulus proksimal (gambar 3) dan memfasilitasi ekskresi glukosa melalui urin, sehingga dapat memperbaiki kontrol glikemik. Pada individu yang sehat, SGLT-2 dapat menyerap kembali sekitar 90\% glukosa. Namun, penghambat
SGLT-2 hanya menghambat sekitar 30-50\% dari beban glukosa yang terfiltrasi (Saraswati, 2016). Peningkatan ekskresi glukosa melalui urin akan menyebabkan kehilangan kalori sehingga dapat mengalami penurunan berat badan. Selain itu, efek lain yang dapat ditimbulkan dari peningkatan ekskresi glukosa melalui urin adalah tekanan darah sistolik menurun (Freeman, 2013).

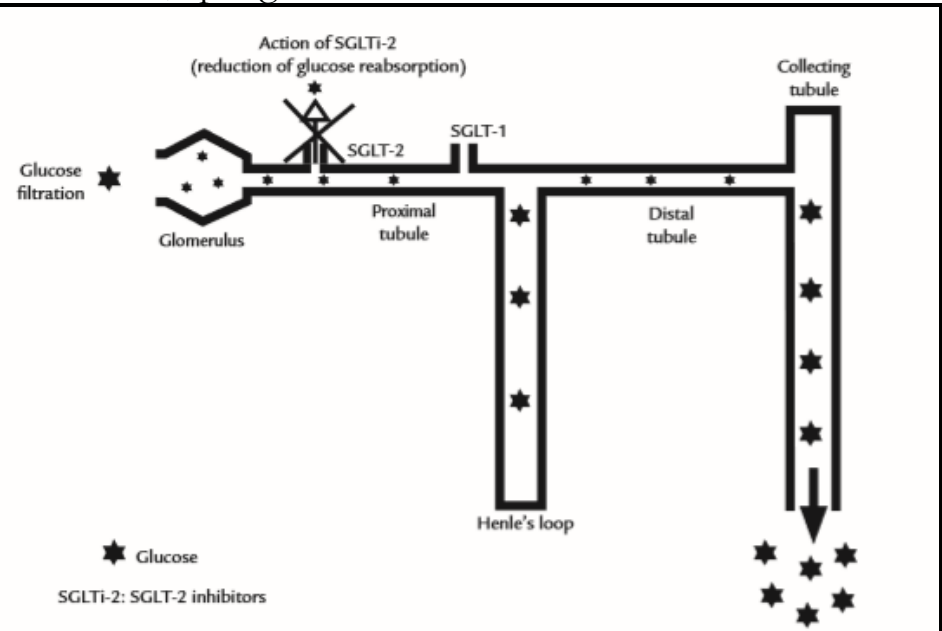

Gambar 3. Mekanisme kerja dari penghambat SGLT-2 (Santos, dkk., 2017).

\section{FARMAKOKINETIK- FARMAKODINAMIK INHIBITOR}

Obat-obat yang termasuk dalam penghambat SGLT-2 adalah empagliflozin, canagliflozin,

dan

dapagliflozin.

SGLT-2

Farmakokinetika dari SGLT-2 inhibitor secara umum menunjukkan bioavailabilitas yang baik saat diberikan melalui oral. SGLT-2 inbibitors memiliki waktu paruh yang lama, 
DOI: https://doi.org/10.24843/JFU.2019.v08.i01.p02

pISSN: 2301-7716; eISSN: 2622-4607

Jurnal Farmasi Udayana, Vol 8, No 1, Tahun 2019, 7-13

dan menghasilkan metabolit yang tidak aktif serta dalam jumlah yang limit diekskresi melalui ginjal (Morris, 2017).

Dapagliflozin merupakan salah satu penghambat SGLT-2 yang diabsorbsi dengan cepat setelah pemberian oral, mencapai kadar puncak dalam waktu 2 jam, dan menunjukkan bioavailabilitas sebesar $78 \%$. Obat ini dimetabolisme oleh enzim uridine diphosphate glucoronosyl transferase (UGT)1A9 di hati dan ginjal. Waktu paruh dari dapaglifozin sekitar 12,9 jam dan dieliminasi melalui urin sebesar 75\% (Kalra, 2014).

Obat lain dari golongan gliflozin seperti empagliflozin dan canagliflozin menunjukkan sedikit perbedaan profil farmakokinetik. Canagliflozin mencapai konsentrasi maksimal dalam plasma sekitar 1-2 jam setelah melalui pemberian oral dengan bioavailabilitas $65 \%$, dan dimetabolisme oleh enzim UGT1A9 dan UGT2B4. Canagliflozin akan dieliminasi melaui urin sebanyak 33\% dengan waktu paruh 10,6 jam. Empagliflozin mencapai kadar puncak dalam plasma dengan kisaran waktu selama 1,5 jam setelah pemberian oral dengan bioavailabilitas sekitar 75,5-77,4\%. Waktu paruh yang dimiliki oleh empagliflozin sekitar 12,4 jam dan sebanyak 54,4\% dieliminasi melalui urin (Saraswati, 2016).

Tabel 1. Profil farmakokinetika penghambat SGLT-2

\begin{tabular}{cr}
\hline & Canagliffoz \\
\hline Absorbsi $\left(\mathrm{T}_{\max }\right)$ & $1-2$ ja \\
Bioavailabilitas & $65 \%$ \\
Ikatan Protein & $99 \%$ \\
Metabolisme & glukoron \\
Waktu Paruh & $10,6-13,1$ \\
Eliminasi melalui urin & $33 \%$ \\
Penghambat SGLT-2 tidak \\
menunjukkan interaksi dengan obat lain, \\
termasuk obat antidiabetes dan diuretik. Pada \\
diabetes melitus tipe 2, obat ini \\
dikombinasikan dengan $\quad$ metformin, \\
sulfonylurea, pioglitazone, sitagliptin, dan \\
voglibose. Meskipun tidak ada interaksi \\
langsung, penggunaan obat ini bersamaan \\
dengan diuretik sebaiknya dihindari untuk \\
mencegah dan menghindari deplesi cairan \\
(Saraswati, 2016). \\
5. PENGGUNAAN KLINIS SGLT-2 \\
INHIBITOR
\end{tabular}

Inhibitor SGLT-2 dapat digunakan untuk penderita diabetes melitus tipe 2 dengan kadar glukosa darah tinggi disamping pemberian metformin dan insulin, akan tetapi inhibitor SGLT-2 tidak dianjurkan untuk penderita dengan gangguan ginjal. Efek

\begin{tabular}{cc} 
Dapagliflozin & Empagliflozin \\
\hline 2 jam & 1,5 jam \\
$75 \%$ & $75,5-77,4 \%$ \\
$91 \%$ & $86,2 \%$ \\
glukoronidasi & glukoronidasi \\
12,9 jam & 12,4 jam \\
$75 \%$ & $54,4 \%$
\end{tabular}

samping yang dapat ditimbulkan dari
pemberian inhibitor SGLT-2 adalah glukosuria yaitu glukosa yang banyak dikeluarkan melalui urin, dimana hal tersebut dapat menyebabkan infeksi saluran urogenital. Efek samping jenis ini lebih mungkin dapat terjadi pada wanita dibandingkan pria. Seperti contoh, insidensi vulvovaginitis dan balanitis terhadap seseorang yang mendapatkan terapi dapagliflozin sebesar 5,5\% (Morris, 2017).

Pemberian inhibitor SGLT-2 dengan insulin, sulfonylurea, atau glinid dapat meningkatkan risiko hipoglikemia. Penghambat SGLT-2 dapat menyebabkan kondisi yang berbahaya yang disebut sebagai ketoasidosis diabetik, tetapi hal ini jarang terjadi. Penghambat SGLT-2 tidak bisa diberikan pada seseorang dengan kondisi diabetes melitus tipe 1, infeksi urogenital, 
DOI: https://doi.org/10.24843/JFU.2019.v08.i01.p02

pISSN: 2301-7716; eISSN: 2622-4607

Jurnal Farmasi Udayana, Vol 8, No 1, Tahun 2019, 7-13

elevasi haematocrit, ibu hamil dan menyusui (Morris, 2017).

Diabetes melitus merupakan faktor risiko terjadinya penyakit ginjal kronik (PGK) dan penyakit kardiovaskuler (PKV). Adanya mekanisme penghambatan pada SGLT-2 akan memberikan manfaat terhadap sistem reno-kardiovaskuler melalui penurunan glukosa darah, berat badan, dan tekanan darah (Saraswati, 2016).

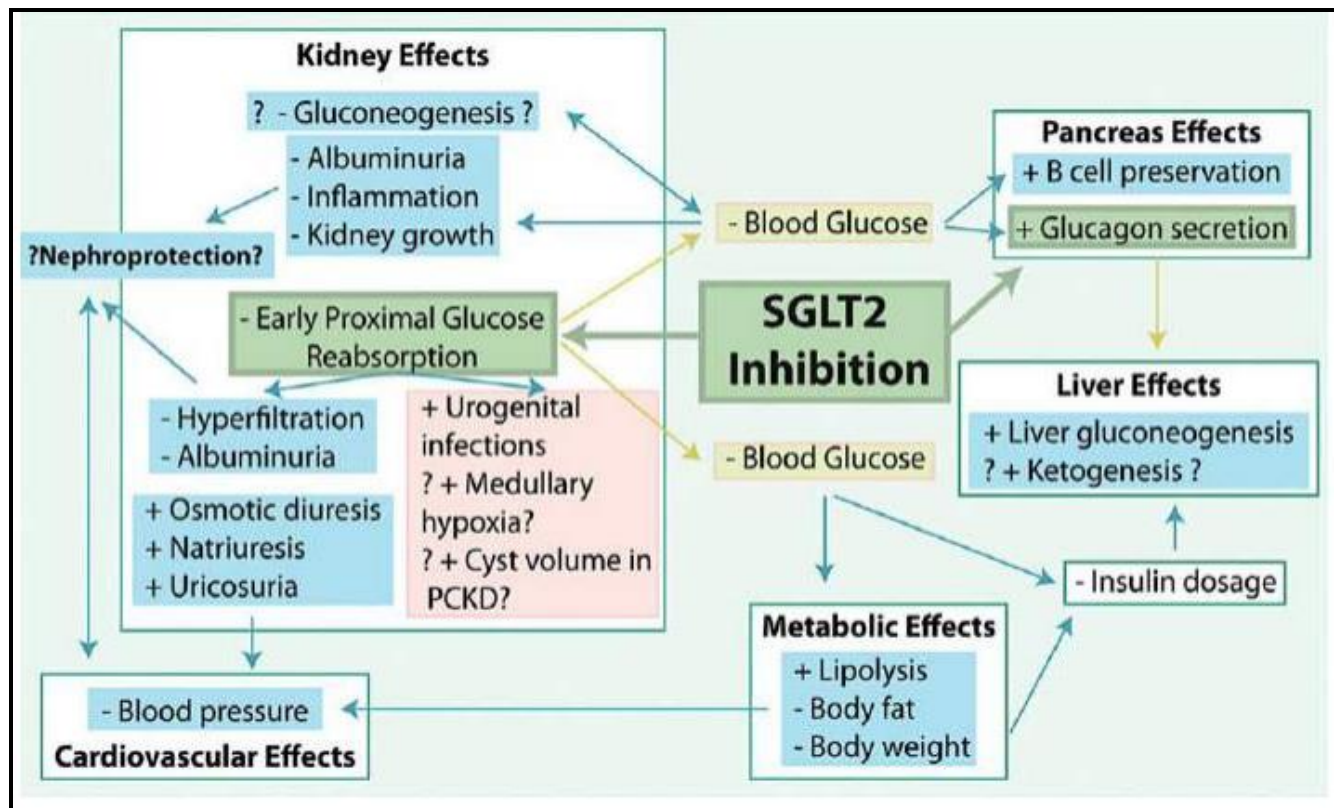

Gambar 4. Efek langsung dan tak langsung penghambatan SGLT-2 pada ginjal dan organ lainnya (Suastika, dkk., 2017).

Pada PGK, penghambatan SGLT-2 dapat menurunkan hiperfiltrasi glomerulus di samping penurunan glukosa darah (gambar 4). Penghambatan SGLT-2 tidak menunjukkan manfaat terhadap glumerulosklerosis, atrofi tubuler, atau fibrosis tubulointerstisial seperti yang ditunjukkan oleh antagonis reseptor AT1 angiotensin II (Suastika, dkk., 2017).

Efek perbaikan kadar glukosa darah oleh penghambat SGLT-2 telah dikemukakan pada beberapa penelitian. Studi yang dilakukan oleh Bailey et al. tahun 2013 menunjukan penggunaan dapagliflozin 2,5; 5; dan $10 \mathrm{mg}$ selama 102 minggu memiliki efek penurunan berat badan tanpa peningkatan risiko hipoglikemia, penurunan $\mathrm{HbA1c}$ masing-masing sebesar $0,48 \% ; 0,58 \% ; 0,78 \%$, dan penurunan kadar glukosa darah puasa sebesar 1,07-1,47 mmol/l. Penelitian yang dilakukan oleh Inagaki et al. tahun 2014 dalam penggunaan canagliflozin sebagai terapi tambahan antidiabetik oral atau monoterapi menunjukkan penurunan signifikan kontrol kadar glukosa darah. Hal ini ditunjukkan dengan penurunan $\mathrm{HbA} 1 \mathrm{c}$ dari $0,8-1,06 \%$ dan $0,93-1,26 \%$ masingmasing pada penggunaan canagliflozin 100 $\mathrm{mg}$ dan $200 \mathrm{mg}$ dan efek penurunan berat badan yang bertahan selama 52 minggu pengobatan. Hal yang sama juga ditunjukka oleh penelitian yang dilakukan oleh Stenlof et al. tahun 2012 yang menyebutkan bahwa penghambat SGLT-2 memiliki beberapa efek tambahan yang dapat bermanfaat untuk sindrom metabolic, seperti penurunan berat badan, penurunan tekanan darah (terutama sistolik), serta penurunan asam urat serum (Suastika, dkk., 2017). 
DOI: https://doi.org/10.24843/JFU.2019.v08.i01.p02

pISSN: 2301-7716; eISSN: 2622-4607

Jurnal Farmasi Udayana, Vol 8, No 1, Tahun 2019, 7-13

Penghambat SGLT-2 telah diakui oleh FDA sebagai obat untuk terapi DM tipe 2, namun belum diakui untuk pengobatan DM tipe 1. Dalam guideline, American Diabetes Association (ADA) menggunakan metformin sebagai obat lini pertama. Jika tidak berhasil selama 3 bulan pengobatan dengan dosis optimal, maka salah satu obat oral atau insulin bisa ditambahkan sebagai obat kedua setelah metformin, termasuk penghambat SGLT-2 (Kalra, 2014).

\section{KESIMPULAN}

Diabetes melitus merupakan suatu kondisi medis yang ditandai dengan adanya peningkatan kadar glukosa dalam darah yang melebihi batas normal. Selain terapi konvensional, terdapat terapi baru yang digunakan untuk mengatasi penyakit diabetes melitus tipe 2, salah satu diantaranya adalah penghambat SGLT-2. Penghambat SGLT-2 bekerja dengan cara menghambat reabsorbsi glukosa yang terjadi di ginjal, sehingga kadar glukosa dalam plasma dapat diturunkan. Selain efek untuk menurunkan kadar glukosa darah, penghambat SGLT-2 juga memiliki

Freeman, J. S. 2013. Review of insulindependent and insulin-independent agents for treating patients with type 2 diabetes melitus and potential role for sodium-glucose co-transporter 2 inhibitors. Postgrad Med. 125(3): 14-26.

Kalra, S. 2014. Sodium Glucose Cotransporter-2 (SGLT-2) Inhibitors: A Review of Their Basic and Clinical Pharmacology. Diabetes Ther. Vol. 5. 355-366.

Luman, A. 2015. Peran Inhibitor Sodium Glucose Co-transporter 2 (SGLT2) pada Terapi Diabetes Melitus. CDK230. 42(7): 498-500. beberapa efek tambahan yaitu dapat menurunkan berat badan dan tekanan darah. Bioavailabilitas dari SGLT-2 inhibitor menunjukkan profil yang baik apabila diberikan secara oral.

\section{UCAPAN TERIMA KASIH}

Penulis mengucapkan terima kasih kepada semua pihak yang telah memberikan segala bentuk dukungan terhadap penulisan review ini.

\section{DAFTAR PUSTAKA}

Chao, E. C. 2014. SGLT-2 Inhibitors: A New Mechanism for Glycemic Control. Clinical Diabetes. 32(1): 4-11.

Chen, L. H. dan P. S. Leung. 2013. Inhibition of the sodium glucose transporter-2: its beneficial action and potential combination therapy for type 2 diabetes mellitus. Diabetes Obes Metab. 15(5): 392-402.

Edward, C. dan D.O. Chao. 2014. SGLT-2 Inhibitors: A New Mechanism for Glycemic Control. 32(1): 4-11.

Morris, D. 2017. The SGLT2 inhibitors where are we now? Journal of Diabetes Nursing. 21(5): 162-165.

PERKENI, 2006. Konsensus Pengelolaan dan Pencegahan Diabetes Melitus Tipe 2 di Indonesia. Jakarta: Perkumpulan Endrokrinologi Indonesia.

Saraswati, M. R. 2016. Bali Endocrinologi Update (BEU XIII) Endocrinology and Beyond. Denpasar: PT. Percetakan Bali.

Suastika, K., A. A. G. Budhiarta, W. Gotera, M. R. Saraswati, dan I M. P. Dwipayana. 2017. Bali Endocrinologi Update (BEU XIV): Improving Management of Endocrine Disorder in Clinical Practice. Denpasar: PT. Percetakan Bali. 